園学雑. (J. Japan. Soc. Hort. Sci.) 53(3) : 338-346. 1984.

\title{
予備冷蔵の有無と冷蔵温度が促成ボタンの生育及び 切花品質に及湆す影響
}

\author{
青木 宣明・吉野 蕃人 \\ 島根大学農学部 690-11 松江市上本庄町
}

\author{
Effects of Precooling and the Temperature of Cold Storage on the \\ Growth and the Quality of Cut Flowers of Forced \\ Tree Paeony (Paeonia suffruticosa Andr.) \\ Noriaki Aoki and Shigeto Yoshino \\ Faculty of Agriculture, Shimane University, Kamihonjocho, \\ Matsue, Shimane 690-11
}

\section{Summary}

The present study was undertaken to clarify the effects of precooling and temperature of cold storage on the growth and quality of cut flowers of forced tree paeony (Paeonia suffruticosa Andr. cv. 'Hanakisoi').

Experiment 1 .

1. The number of petals at the start of cold storage increased with duration of precooling at $15^{\circ} \mathrm{C}$. The stage of flower bud differentiation was promoted by precooling.

2. Sprouting and flowering time occurred earlier following precooling; after cold storage at $0^{\circ} \mathrm{C}$ without precooling, sprouting time was delayed for 1 or 2 weeks and the flowering time for 2 weeks or more.

3. The percentage of flowering was highest after precooling for 3 weeks and cold storage at $4{ }^{\circ} \mathrm{C}$ and was lowest after precooling for 3 weeks and cold storage at $0^{\circ} \mathrm{C}$.

4. The quality of cut flowers was high when the plants were kept in cold storage at $4^{\circ} \mathrm{C}$ or $0^{\circ} \mathrm{C}$ after precooling for 3 weeks, but was poor when kept in cold storage at $0{ }^{\circ} \mathrm{C}$ without precooling.

5. The number of petals of cut flowers decreased with precooling for 2 weeks or more.

Experiment 2.

1. Sprouting and flowering time was markedly promoted and the quality of cut flowers improved with precooling. However, the number of petals of cut flowers decreased. These results were almost similar to experiment 1 .

2. The percentage of flowering was high in all treatments.

These results show that, in the forcing of 2 year-old plants, it is most efficient to precool for 3 weeks and cold store at $4^{\circ} \mathrm{C}$. It was also suggested that 3 or 4 yearold plants can be kept in cold storage at $0^{\circ} \mathrm{C}$ for 6 weeks if they are first precooled.

\section{緒言}

筆者らは前報(1)において, 花芽の発育経過を調査し, さらに $0^{\circ} \mathrm{C}$ 冷蔵期間が促成ボタンの生育や切花品質に 与える影響について調査し報告した。 その結果, 雄ずい

1 1984年 4 月23日受理

ボタンの促成に関する研究. 第 2 報.

本研究の一部は文部省科学研究費補助金によって行 われた。
の分化は 9 月下旬ごろから開始され，その時期前後から $6 \sim 7$ 週問冷蔵後の促成ボタンは切花としての草姿が良 好であり，4, 5, 6, 7 週間の冷蔵期間内では, 冷蔵期間が 長くなるほど開花期が早くなる利点があった。しかしな がら，冷蔵期間が長くなるほど冷蔵開始時期が早くなる ため，開花率の低下が認められた．したがって，切花と しての草姿が良好でしかも開花率の向上を目指すために は, 本冷蔵開始時をでに花芽形成を促進させる予備冷蔵 


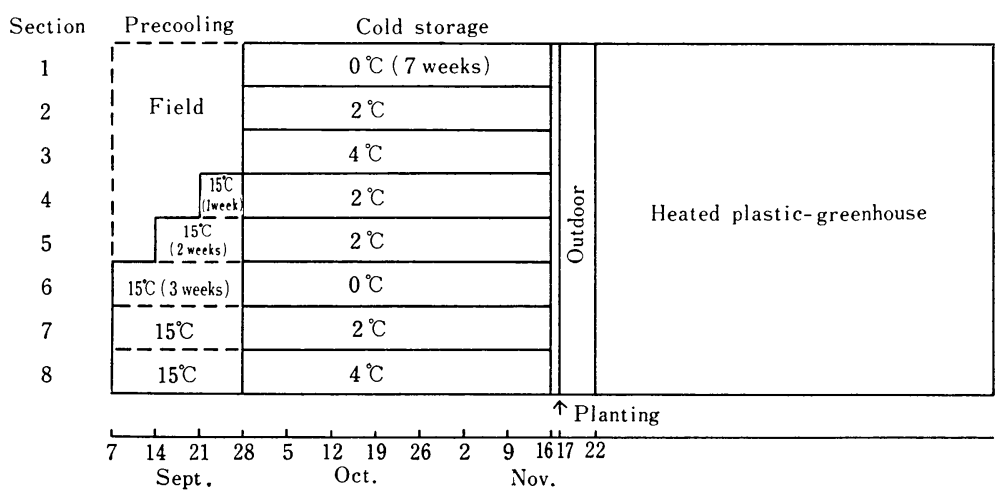

Fig. 1. The outline of experimental design (experiment 1).

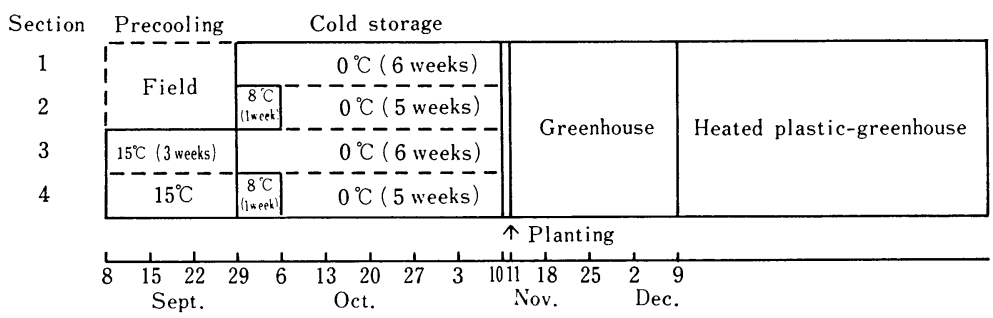

Fig. 2. The outline of experimental design (experiment 2).

や，さらに本冷蔵温度などの検討が必要である。

本実験では，まず尒備冷蔵の有無が花芽の発育にぞの ような影響を与えるかを調査した。次に予備冷蔵の有無 と本冷蔵温度の組み合わせが促成ボタンの生育, 開花, 切花品質に及ぼす影響について調べたので，その結果を 報告する。

\section{材料及び方法}

本実験は，島根県八束町（大根島）で生産されたボタ ン“花競’の接ぎ木 2 年生株及び 島根大学で生産された $3 \sim 4$ 年生株を供試し, 島根大学農学部附属農場におい て実施した。

\section{実験 1.}

2 年生株を供試し 第 1 図に示すように, 1983 年 9 月 28 日から $0,2,4^{\circ} \mathrm{C}$ でそれぞれ 7 週間本冷蔵する区と, それぞれの冷蔵温度に対し，9月 7 日に株を掘り上げ, 9 月 28 日まで $15^{\circ} \mathrm{C}$ で 3 週間予備冷蔵する区を設け た。また $2^{\circ} \mathrm{C}$ 冷蔵については, 予倫冷蔵開始日を变え て，期間を 1 週間及び 2 週間とする区を設け，計 8 処理 区を設定した。なお，株の冷蔵は湿らせた水苔で根を包 む湿式とした。

花芽の発育を調査するため，9月 7 日から 28 日まで 1 週間ごとに 4 回, 固場から 2 年生株の頂芽を 10 個体
ずつ採取し，解剖顕微鏡下で観察した。 また，予倫冷蔵 の期間が花芽の発育に与える影響を調查するため, 予濊 冷蔵終了時の 9 月 28 日にそれぞれの予供冷蔵期間の区 から株の頂芽を 10 個体ずつ採取し観察した。

11 月 16 日，株を出庫し 1 日間室温に慣らしたのち, 11 月 17 日 8 号鉢に 1 株ずつ植光付けた。なお，供試株 数は各区とも 16 株とした. 植光付け後から 6 日間は, 初期の発育を順調に導くため, 屋外の涼しい場所で管理 した. 11 月 22 日通常のビニルハウスに搬入後, 11 月 30 日から加温を開始した。

加温開始後の温度管理は, 昼間室温 $20^{\circ} \mathrm{C}$, 夜間 $15^{\circ} \mathrm{C}$ を目標とした。促成中の栽培温度は, 鉢上 $20 \mathrm{~cm}$ の位置 を 1 時間ごとに測定し，昼温（ 9 時〜20 時）と夜温（21 時〜8時）に分けて整理した.

植之付け後萠芽期まで，株の頂芽部に対し毎日 $1 \sim 2$ 回シリンジを行った．花蕾から花弁の花色が見光始めた 日を開花日とし，花弁が完全に開いた日に新梢部を切断 し，切花形質の調查を行った。 切花形質として，切花 重, 新梢の長さ，花の大きさ，花弁数，葉面積などを調

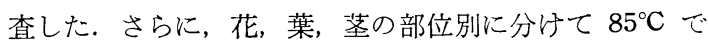
2 週間乾燥させ, 乾物重及び乾物割合を求めた。

\section{実験 2 .}


Table 1. Effect of the duration of precooling on the growth of flower buds in tree paeony (Paeonia suffruticosa Andr.) (experiment 1).

\begin{tabular}{|c|c|c|c|c|c|c|c|c|c|}
\hline \multirow{2}{*}{ Sampling date } & \multicolumn{2}{|c|}{ Bud } & \multirow{2}{*}{$\begin{array}{l}\text { Number } \\
\text { of scales }\end{array}$} & \multicolumn{2}{|c|}{ Flower bud ${ }^{z}$} & \multirow{2}{*}{$\begin{array}{l}\text { Number } \\
\text { of leaves }\end{array}$} & \multicolumn{2}{|c|}{ Flower } & \multirow{2}{*}{$\begin{array}{l}\text { Number } \\
\text { of petals }\end{array}$} \\
\hline & $\begin{array}{l}\text { Diameter } \\
(\mathrm{mm})\end{array}$ & $\begin{array}{l}\text { Length } \\
(\mathrm{mm})\end{array}$ & & $\begin{array}{l}\text { Diameter } \\
(\mathrm{mm})\end{array}$ & $\begin{array}{l}\text { Length } \\
(\mathrm{mm})\end{array}$ & & $\begin{array}{l}\text { Diameter } \\
(\mathrm{mm})\end{array}$ & $\begin{array}{l}\text { Length } \\
(\mathrm{mm})\end{array}$ & \\
\hline \multicolumn{10}{|l|}{ Non treated } \\
\hline Sept. 7 & $7.9^{\mathbf{y}}$ & 14.4 & 10.1 & 3.3 & 4.6 & 9.5 & 1.1 & 1.3 & 7.8 \\
\hline Sept. 14 & 8.3 & 15.2 & 9.5 & 3.6 & 4.8 & 9.6 & 1.3 & 1.4 & 9.5 \\
\hline Sept. 21 & 8.0 & 14.4 & 9.7 & 3.8 & 5.7 & 9.3 & 1.4 & 1.8 & 12.2 \\
\hline Sept. $28^{x}$ & 8.2 & 15.3 & 10.3 & 3.6 & 5.2 & 9.0 & 1.4 & 1.8 & 14.6 \\
\hline \multicolumn{10}{|c|}{ Precooled for a week } \\
\hline Sept. $28^{w}$ & 8.5 & 16.1 & 10.3 & 3.8 & 5.4 & 9.2 & 1.6 & 1.9 & 16.5 \\
\hline \multicolumn{10}{|c|}{ Precooled for 2 weeks } \\
\hline Sept. $28^{v}$ & 9.5 & 18.1 & 10.1 & 4.4 & 6.5 & 9.1 & 1.9 & 2.2 & 19.0 \\
\hline \multicolumn{10}{|c|}{ Precooled for 3 weeks } \\
\hline Sept. $28^{u}$ & 9.2 & 17.5 & 10.4 & 4.1 & 6.3 & 9.2 & 1.7 & 2.2 & 18.7 \\
\hline
\end{tabular}

$z$ Measured after removing scales.

y Means of 10 plants.

$x-u$ Stamens were going to form in some sample plants.

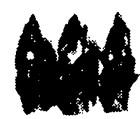

311

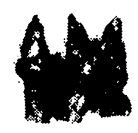

211

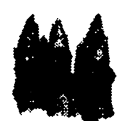

1. II

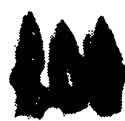

0

132

Fig. 3. Effect of the duration of precooling on the growth of flower buds of tree paeony. Duration of precooling was 3 weeks, 2 weeks, a week and no week from left to right. (Photographed on Sept. 28, 1983)

$3 \sim 4$ 年生株を供試し第 2 図に示すよらに, 1983 年 9 月 29 日から $0^{\circ} \mathrm{C}$ で 6 週間本冷蔵する区と, $8^{\circ} \mathrm{C} 1$ 週 間 $0^{\circ} \mathrm{C} 5$ 週間本冷蔵する区を設定した。 また，それぞれ の冷蔵区に対し，9月 8 日に株を掘り上げ， $15^{\circ} \mathrm{C} て ゙ 3$ 週 間予借冷蔵する区を設定し計 4 区とした。11月 10 日株 を出庫し 1 日間室温に慣らしたのち，11月 11 日 8 号鉢 に 1 株ずつ植え付けたななお，供試株数は各区とも 5 株 とした．植え付け後は温室及びビニルハウスで管理し た.

植え付け後の栽培管理や調查方法については実験 1 に 準じた.

\section{結果}

\section{実 験 1.}

1. 花芽の発育

花芽の発育について調查した結果が第 1 表である。花 芽の調査を開始した 9 月 7 日から本冷蔵開始時の 9 月 28 日までの間に，頂芽及びりん片除去後の 花芽は伸長

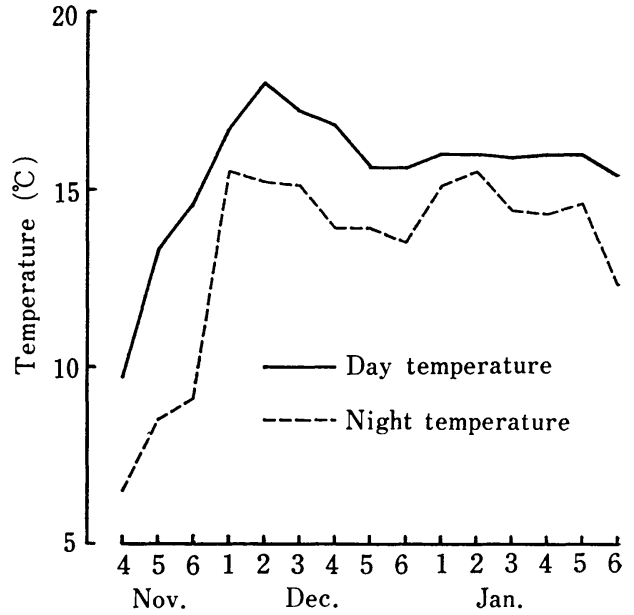

Fig. 4. Day (9:00 20:00) and night (21:00 8:00) temperatures in a greenhouse (means of every 5 days). They were measured $20 \mathrm{~cm}$ above a pot (experiment 1).

肥大がわずかであった，一方，りん片数，葉数はともに 9〜11で, りん片数は前報(1)の結果より $1 \sim 2$ 枚少な く，葉数は前報の結果とほぼ同様であった。

花芽の調查を開始した 9 月 7 日の時点では葉分化はす でに終了し，がく片及び $7 \sim 8$ 枚の花弁の分化が確認さ れた。調查日の経過とともに花弁数は増加し，9月 28 日では 14.6 枚であった．また一部には雄ずい分化中の 個体が観察された。

予備冷蔵によって花升数は增加し， 1 週間処理区で約 2 枚, $2 \sim 3$ 週間処理区では 4 枚強，無処理より多かっ 
Table 2. Effects of precooling and the temperature of cold storage on the sprouting and flowering of forced tree paeony (experiment 1 ).

\begin{tabular}{clllcc}
\hline Section & $\begin{array}{l}\text { Sprouting } \\
\text { date }\end{array}$ & $\begin{array}{l}\text { Flowering } \\
\text { date }\end{array}$ & $\begin{array}{l}\text { Cumulative } \\
\text { temperature } \\
\left({ }^{\mathrm{y}} \mathrm{C} \cdot \text { day }\right)\end{array}$ & $\begin{array}{l}\text { Percent } \\
\text { lower- } \\
\text { ing (\%) }\end{array}$ \\
\hline 1 & Dec. 13e & Jan. 28d & 1,049 & 50.0 \\
2 & Dec. 5d & Jan. 11c & 795 & 62.5 \\
3 & Dec. 4d & Jan. 10bc & 780 & 68.7 \\
4 & Dec. 3c & Jan. 9b & 764 & 68.7 \\
5 & Dec. 1b & Jan. 8ab & 747 & 68.7 \\
6 & Dec. 2bc & Jan. 10b & 780 & 12.5 \\
7 & Nov. 29a & Jan. 9ab & 764 & 31.2 \\
8 & Nov. 30ab & Jan. 7a & 732 & 81.2 \\
\hline
\end{tabular}

$z$ See Fig. 1 .

$y$ From planting to flowering.

$\mathbf{x}, \mathbf{w}$ Means of sprouted or flowered plants, separated by Duncan's multiple range test, $5 \%$ level.

た。 また，予備冷蔵処理期間の長短によって外観上でも 明らかな差が現れた（第 3 図）。すなわち， $2 \sim 3$ 週間処 理区では花芽をとりまくりん片に龟裂が生じ，内部の伸 長肥大が盛んであったことを示している。

\section{2. 促 成}

促成中の栽培温度は第 4 図に示すとおりである，植え 付け後 2 週間は屋外や無加温で栽培管理したため, 半旬 ごとの平均昼温は $15^{\circ} \mathrm{C}$ 以下で維持でき, 夜温は $10^{\circ} \mathrm{C}$ 以下となった。一方, 加温後は日中 $20^{\circ} \mathrm{C}$, 夜間 $15^{\circ} \mathrm{C}$ 前 後を目標として管理した結果，昼温 $16 \sim 17^{\circ} \mathrm{C}$, 夜温 $14 \sim 15^{\circ} \mathrm{C}$ で推移した.

各処理区の萠芽日と開花日は第 2 表に示すとおりであ る，予備冷蔵を施すことによって萠芽は早くなり，しか も期間が長いほど効果的であった。すなわち, 予備冷蔵 3 週間処理の区-7, 8 は萠芽が早く, また, 開花も早くな った. 区-1の萠芽日は他区に比べ $1 \sim 2$ 週間遅れ, 開花
日では 2 週間以上遅延した. 開花率は区-8 が $81.2 \%$ で 最も高く, 区-1, 6,7 は $50 \%$ 以下となり, 中でも区-6 は $12.5 \%$ で最低を示した. 区-1 を除いた他 7 処理区の 積算温度は $732 \sim 795^{\circ} \mathrm{C}$ ・日の範囲にあり, $60^{\circ} \mathrm{C}$ ・日強の差 が生じた.しかし，開花率が低い区-6,7を除いた他 5 処 理区の萠芽から開花までの到花日数は $37 \sim 38$ 日で, そ の間の積算温度は $574 \sim 592^{\circ} \mathrm{C}$ 日旦より, 萠芽から開花 までの到花日数及び積算温度は，この 5 処理区間内では 類似した。

開花時における切花形質は第 3 表に示すとおりであ る. 区-3,6 は花弁数を除いたどの形質についてみても 他の処理区より優れた。 区-1 は切花重や花については 良好であったが，葉の諸形質は全処理区中最も劣った。 予備冷蔵の有無は, 花弁数や葉面積に大きな影響を与え た.まず花弁数では，2 週間以上予備冷蔵を施すと本冷 蔵のみの各処理区に比べ半分近くに激減した. 本冷蔵の みの各処理区では, $0^{\circ} \mathrm{C}$ 冷蔵の区-1 の花弁数は区 $-2,3$ より多く, さらに, 予備冷蔵 3 週間処理区内でも $0^{\circ} \mathrm{C}$ 冷 蔵の区-6は，区-7,8 より多くなる傾向を示した。 ま た，一部の雄ずいが花弁化する現象が認められたが，そ れは 50 枚以上の花弁を有する個体に多く観察された. 次に葉面積では, $0^{\circ} \mathrm{C}$ 冷蔵の場合には予供冷蔵を施すと 葉面積は増大し， $2^{\circ} \mathrm{C}$ 冷蔵でも同様な傾向があった。 し かし， $4^{\circ} \mathrm{C}$ 冷蔵では逆にやや減少した。

各処理区における葉位ごとの葉面積は第 5 図に示すと おりである．最大葉の葉位は，区-6 の第 2 葉目を除き， 各処理区とも第 3 葉であった. 区-6 の最大葉の 葉面積 は全区中最大で, $136 \mathrm{~cm}^{2}$ であった．続いて区-3の 104 $\mathrm{cm}^{2}$ となり, 区-1 は全処理区中最小の $61 \mathrm{~cm}^{2}$ で, 区一 6 の半分以下であった。 また全処理区とも葉面積は最大 葉をピークとして次第に減少したのに対し，区-1 のみ

Table 3. Effect of precooling and the temperature of cold storage on the quality of cut flowers of forced tree paeony (experiment 1 ).

\begin{tabular}{|c|c|c|c|c|c|c|c|c|c|c|}
\hline \multirow[b]{2}{*}{ Section $^{z}$} & \multirow{2}{*}{$\begin{array}{l}\text { Weight of } \\
\text { cut flower } \\
\text { (g) }\end{array}$} & \multirow{2}{*}{$\begin{array}{l}\text { Length of } \\
\text { current } \\
\text { shoot } \\
\quad(\mathrm{cm})\end{array}$} & \multicolumn{2}{|c|}{ Flower } & \multirow{2}{*}{$\begin{array}{l}\text { Number } \\
\text { of petals }\end{array}$} & \multicolumn{3}{|c|}{ Largest leaf } & \multicolumn{2}{|c|}{ Total leaves } \\
\hline & & & $\begin{array}{l}\text { Diameter } \\
(\mathrm{cm})\end{array}$ & $\begin{array}{l}\text { Weight } \\
(\mathrm{g})\end{array}$ & & $\begin{array}{l}\text { Petiole length } \\
\text { (cm) }\end{array}$ & $\begin{array}{l}\text { Width } \\
(\mathrm{cm})\end{array}$ & $\begin{array}{l}\text { Length } \\
(\mathrm{cm})\end{array}$ & $\begin{array}{l}\text { Weight } \\
\text { (g) }\end{array}$ & $\begin{array}{l}\text { Area } \\
\left(\mathrm{cm}^{2}\right)\end{array}$ \\
\hline 1 & $39.5 \mathrm{ab}^{\mathrm{y}}$ & $30.4 \mathrm{~b}$ & $16.9 \mathrm{a}$ & $26.0 \mathrm{a}$ & $79.8 \mathrm{a}$ & $5.1 \mathrm{c}$ & $13.5 \mathrm{ac}$ & $14.7 \mathrm{c}$ & $6.0 \mathrm{~d}$ & $265 \mathrm{~d}$ \\
\hline 2 & $35.2 \mathrm{bc}$ & $30.9 b$ & $14.7 \mathrm{bc}$ & $17.4 \mathrm{~b}$ & $64.3 \mathrm{~b}$ & $7.7 \mathrm{~b}$ & 13. $3 \mathrm{bc}$ & $17.5 \mathrm{~b}$ & $9.7 \mathrm{c}$ & $411 \mathrm{~cd}$ \\
\hline 3 & $45.1 \mathrm{a}$ & $35.7 \mathrm{a}$ & $15.7 \mathrm{ab}$ & $21.0 \mathrm{~b}$ & $61.0 \mathrm{~b}$ & $8.6 \mathrm{ab}$ & $16.7 \mathrm{a}$ & $20.7 \mathrm{ab}$ & $14.1 \mathrm{ab}$ & $599 a b$ \\
\hline 4 & $36.4 \mathrm{~b}$ & $31.2 b$ & $14.0 \mathrm{bc}$ & $16.5 \mathrm{c}$ & $61.3 \mathrm{~b}$ & $9.3 \mathrm{a}$ & 13. $5 \mathrm{bc}$ & $19.0 \mathrm{~b}$ & $11.0 \mathrm{bc}$ & $413 c$ \\
\hline 5 & $29.3 \mathrm{c}$ & $29.5 b$ & $13.8 \mathrm{c}$ & $12.3 \mathrm{~d}$ & $39.4 \mathrm{c}$ & $8.8 \mathrm{ab}$ & 13. $0 \mathrm{c}$ & $18.3 \mathrm{~b}$ & $9.4 \mathrm{c}$ & $377 \mathrm{c}$ \\
\hline 6 & 47. $6 \mathrm{ab}$ & $33.4 \mathrm{ab}$ & 15. $1 \mathrm{abc}$ & 19. $1 \mathrm{abc}$ & $45.5 \mathrm{bc}$ & $11.5 \mathrm{a}$ & $18.9 a$ & $24.8 \mathrm{a}$ & $17.9 a$ & $715 a$ \\
\hline 7 & $36.9 \mathrm{abc}$ & $32.6 \mathrm{ab}$ & $14.8 \mathrm{abc}$ & 15. 3cd & $31.4 \mathrm{c}$ & 9. $4 \mathrm{ab}$ & $15.4 \mathrm{ac}$ & 19. $7 \mathrm{abc}$ & $12.9 \mathrm{ac}$ & $500 \mathrm{ac}$ \\
\hline 8 & $36.7 \mathrm{~b}$ & $31.1 \mathrm{~b}$ & $15.2 \mathrm{~b}$ & $15.2 \mathrm{c}$ & $33.7 \mathrm{c}$ & $8.9 a b$ & $14.9 \mathrm{ab}$ & 19.7ab & $12.0 \mathrm{ac}$ & $452 \mathrm{bc}$ \\
\hline
\end{tabular}

z See Fig. 1.

y Means of flowered plants, separated by Duncan's multiple range test, $5 \%$ level. 


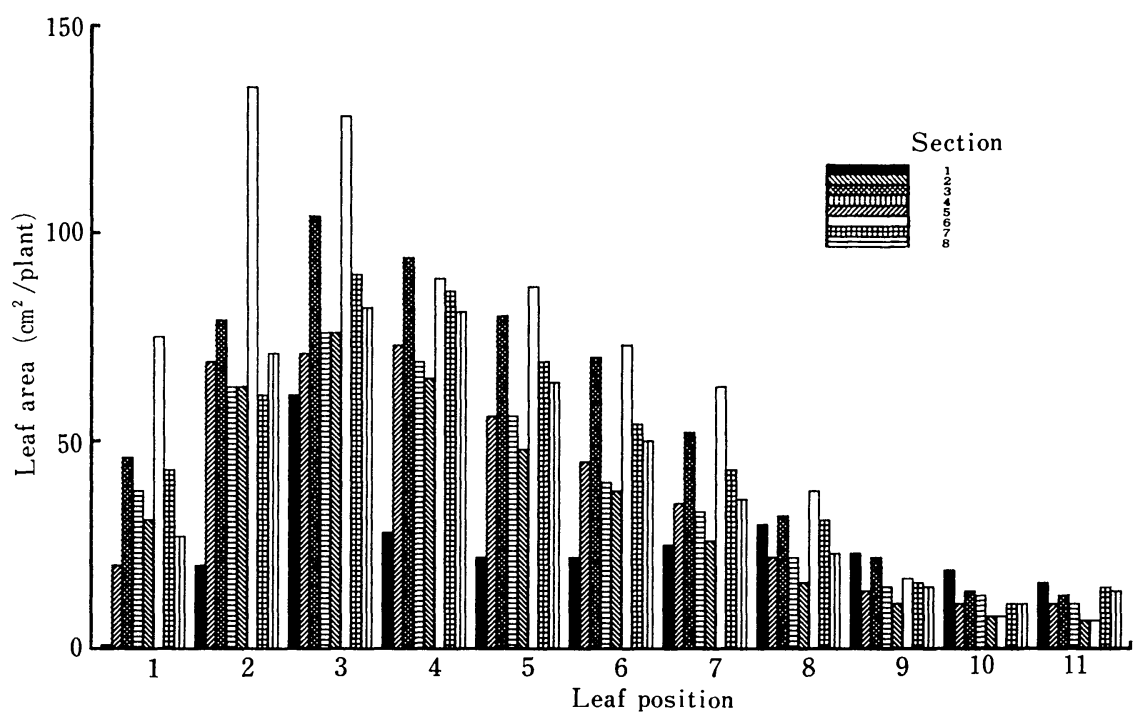

Fig. 5. Effect of precooling and the temperature of cold storage on the area of leaves of cut floweres of forced tree paeony (experiment 1).

は第8葉目にも小さなピークが認められた.

促成ボタンの乾物重は第 4 表に示すとおりである. 区-1 の茎乾重量や葉乾重量は他 7 処理区上り劣った. しかし, 花乾重量では他処理区より優れた。 区- 5 の葉乾 重量や花乾重量も他処理区より劣った。個体乾重量では 区-1, 5 が他処理区より劣った. 器官別乾物割合では, 区-1の茎や葉は他処理区より低率となり，逆に花では 他処理区より著しく高率となった。本冷蔵のみの処理区 間内では, 葉の比率は冷蔵温度が高くなるほど, 花では 逆に冷蔵温度が低くなるほど増大した。予供冷蔵を施し た処理区間内では，前述と全く逆のパターンを示した。
一方 $2^{\circ} \mathrm{C}$ 冷蔵の 4 処理区については, 葉では予備冷蔵期 間が長くなるほど，花では逆に短くなるほど，それぞれ の割合は增大した，茎では一定の傾向が認められなかっ た.

\section{実験 2.}

予借冷蔵開始時における花芽の状態は第 5 表に示すと おりである. 実験 1 飞供試した 2 年生株の頂芽に比べ, 外観上での径や長さはかなり勝っていたが，りん片除去 後の花芽や花の大きさはほぼ等しく, 花弁数は 6.8 枚で 逆に 1 枚活ど少なかった。

促成中の栽培温度は第 6 図に示すとおりである。植え

Table 4. Effect of precooling and the temperature of cold storage on the dry matter of cut flowers of forced tree paeony (experiment 1).

\begin{tabular}{|c|c|c|c|c|c|c|c|}
\hline \multirow[b]{2}{*}{ Section $^{z}$} & \multicolumn{4}{|c|}{ Dry matter } & \multicolumn{3}{|c|}{ Partition of dry matter } \\
\hline & $\begin{array}{l}\text { Stem } \\
(\mathrm{g})\end{array}$ & $\begin{array}{l}\text { Leaf } \\
(\mathrm{g})\end{array}$ & $\begin{array}{l}\text { Flower } \\
(\mathrm{g})\end{array}$ & $\begin{array}{l}\text { Total } \\
(\mathrm{g})\end{array}$ & Stem & $\begin{array}{l}\text { Leaf } \\
\text { (\% of total dry matter) }\end{array}$ & Flower \\
\hline 1 & $1.23 b^{y}$ & $1.28 \mathrm{~d}$ & 4. $03 a$ & $6.54 b c$ & $18.8(25.7)^{\times} \mathrm{d}$ & $18.5(25.4) \mathrm{c}$ & $62.6(52.3) \mathrm{a}$ \\
\hline 2 & $1.65 a$ & 2. $47 \mathrm{bc}$ & 3. $30 \mathrm{bc}$ & 7. $42 \mathrm{ac}$ & $22.2(28.1) b c$ & $32.5(34.7) b$ & $45.4(41.7) \mathrm{b}$ \\
\hline 3 & $1.90 \mathrm{a}$ & 3. $28 \mathrm{ab}$ & 3. $69 \mathrm{ab}$ & $8.87 a$ & $21.6(27.6) \mathrm{c}$ & $36.3(36.9) a b$ & $42.1(40.4) \mathrm{bc}$ \\
\hline 4 & $1.78 \mathrm{a}$ & 2. $76 \mathrm{bc}$ & 3. $18 \mathrm{bc}$ & $7.72 \mathrm{ac}$ & $23.3(28.8) a b$ & $35.1(36.3) \mathrm{ab}$ & $41.6(40.1) \mathrm{bd}$ \\
\hline 5 & $1.61 \mathrm{a}$ & $2.42 \mathrm{c}$ & $2.47 \mathrm{~d}$ & $6.50 \mathrm{c}$ & $24.5(29.6) \mathrm{a}$ & $37.4(37.7) \mathrm{a}$ & $38.0(38.0) \mathrm{cd}$ \\
\hline 6 & $2.22 \mathrm{a}$ & $4.49 a$ & $3.80 \mathrm{ac}$ & $10.51 \mathrm{a}$ & $21.3(27.4) \mathrm{acd}$ & $43.1(41.0) \mathrm{a}$ & $35.6(36.6) \mathrm{cd}$ \\
\hline 7 & $1.77 \mathrm{a}$ & 3. $36 \mathrm{ac}$ & $2.86 \mathrm{c}$ & 7. $99 \mathrm{ac}$ & $22.9(28.5) \mathrm{ac}$ & $40.6(39.0) \mathrm{a}$ & $36.5(37.1) \mathrm{d}$ \\
\hline 8 & $1.92 \mathrm{a}$ & 3. $14 \mathrm{ac}$ & $2.92 \mathrm{c}$ & $7.98 \mathrm{ab}$ & $25.8(30.5) \mathrm{a}$ & $37.9(38.0) a b$ & $37.8(37.9) \mathrm{cd}$ \\
\hline
\end{tabular}

z See Fig. 1.

y Means of flowered plants, separated by Duncan's multiple range test, $5 \%$ level.

$x \operatorname{Arcsin} \sqrt{\text { percentage. }}$ 
Table 5. Growth of flower bud in tree paeony at the beginning of precooling (Sept. 8, 1983) (experiment 2).

\begin{tabular}{|c|c|c|c|c|c|c|c|c|}
\hline \multicolumn{2}{|c|}{ Bud } & \multirow{2}{*}{$\begin{array}{l}\text { Number of } \\
\text { scales }\end{array}$} & \multicolumn{2}{|c|}{ Flower bud ${ }^{z}$} & \multirow{2}{*}{$\begin{array}{l}\text { Number of } \\
\text { leaves }\end{array}$} & \multicolumn{2}{|c|}{ Flower } & \multirow{2}{*}{$\begin{array}{l}\text { Number of } \\
\text { petals }\end{array}$} \\
\hline $\begin{array}{l}\text { Diameter } \\
(\mathrm{mm})\end{array}$ & $\begin{array}{l}\text { Length } \\
(\mathrm{mm})\end{array}$ & & $\begin{array}{l}\text { Diameter } \\
\quad(\mathrm{mm})\end{array}$ & $\begin{array}{l}\text { Length } \\
(\mathrm{mm})\end{array}$ & & $\begin{array}{l}\text { Diameter } \\
\quad(\mathrm{mm})\end{array}$ & $\begin{array}{l}\text { Length } \\
(\mathrm{mm})\end{array}$ & \\
\hline 9.1 & 17.9 & 9.8 & 3.6 & 4.5 & 10.6 & 1.1 & 1.2 & 6.8 \\
\hline
\end{tabular}

z Measured after removing scales.

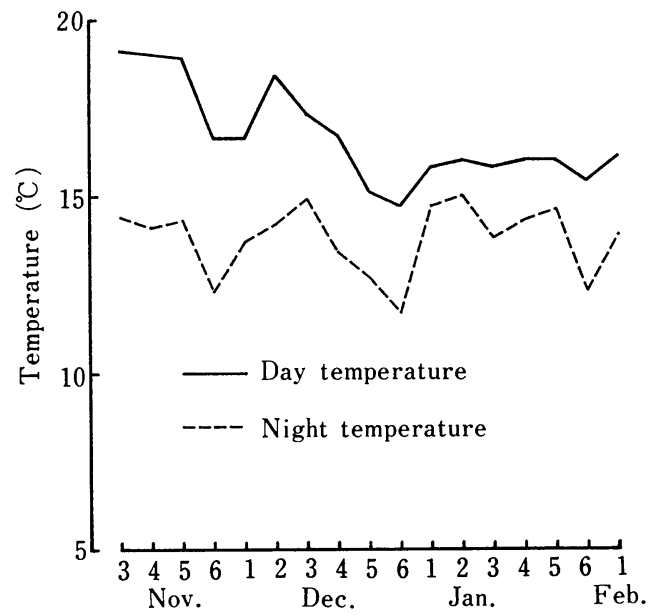

Fig. 6. Day (9:00 20:00) and night (21:00 8:00) temperatures in a greenhouse (means of every 5 days). They were measured $20 \mathrm{~cm}$ above a pot (experiment 2).

付け直後から加温栽培した結果, 半旬ごとの平均昼温は 絶えず $15^{\circ} \mathrm{C}$ 以上, 夜温は $12 \sim 15^{\circ} \mathrm{C}$ で推移した。

各処理区の萠芽日と開花日は第 6 表に示すとおりであ る。また，萠芽後から開花までの新㮐長の生育は第 7 図 に示すとおりである，実験 1 の場合と同様，萠芽が早い 区ほど早く開花に至った。すなわち，予備冷蔵を施した 区-3, 4 の萠芽は早く, 本冷蔵のみの区-1,2 より 10 24

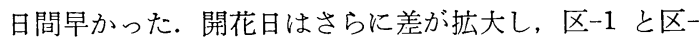
3 の差は 1 か月であった。予備冷蔵処理区問では萠芽日 に有意差は生じなかったが，開花日では区-3 と区-4 の 間に 4 日間の差が生じた。本冷蔵のみの処理区間では, 区-1 の萠芽及び開花は区-2 のそれより 2 週間前後遅延 した。積算温度は区-3 の $842^{\circ} \mathrm{C} ・$ 日が最小で，実験 1 の 場合より温度要求が高かった。また，萠芽から開花まで の到花日数は，区-1を除いた他 3 処理区で $44 \sim 47$ 日と なり，実験 1 の場合より 7 日前後多かった。開花率は全
Table 6. Effects of precooling and the temperature of cold storage on the sprouting and flowering of forced tree paeony (experiment 2).

\begin{tabular}{clllccc}
\hline \hline Section $^{z}$ & $\begin{array}{l}\text { Sprouting } \\
\text { date }\end{array}$ & $\begin{array}{l}\text { Flowering } \\
\text { date }\end{array}$ & $\begin{array}{l}\text { Cumulative } \\
\text { temperature } \\
\text { ( }{ }^{\mathrm{O}} \text {-day) }\end{array}$ & $\begin{array}{l}\text { Percent } \\
\text { flower- } \\
\text { ing (\%) }\end{array}$ \\
\hline 1 & Dec. $16 \mathrm{c}^{\mathrm{x}}$ & Feb. & $5 \mathrm{~d}^{\mathrm{w}}$ & 1,426 & 80 \\
2 & Dec. & $3 \mathrm{~b}$ & Jan. & $18 \mathrm{c}$ & 1,141 & 100 \\
3 & Nov. 22a & Jan. & $5 \mathrm{a}$ & 842 & 100 \\
4 & Nov. 23a & Jan. & $9 \mathrm{~b}$ & 903 & 80 \\
\hline
\end{tabular}

$z$ See Fig. 2.

y From planting to flowering.

$\mathrm{x}, \mathrm{w}$ Means of sprouted or flowered plants, separated by Duncan's multiple range test, $5 \%$ level.

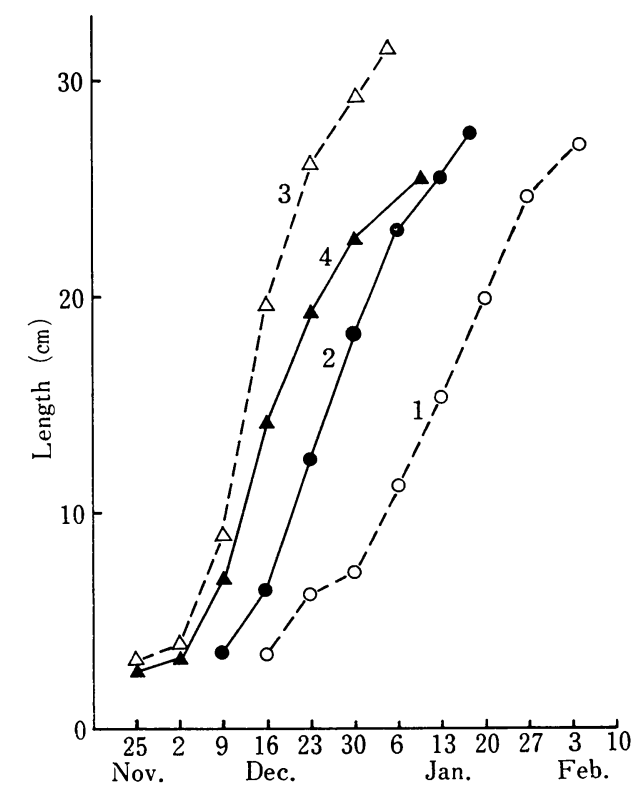

Fig. 7. Effect of precooling and the temperature of cold storage on the growth of current shoots of forced tree paeony (experiment 2).

As to symbols, refer to Fig. 2.

処理区とも 80 ～100\% となり高率であった.

開花時における切花形質は第 7 表に示すとおりであ 
Table 7. Effect of precooling and the temperature of cold storage on the quality of cut flowers of forced tree paeony (experiment 2).

\begin{tabular}{|c|c|c|c|c|c|c|c|c|c|c|}
\hline \multirow{2}{*}{ Section ${ }^{z}$} & \multirow{2}{*}{$\begin{array}{c}\text { Weight of } \\
\text { cut flower } \\
\text { (g) }\end{array}$} & \multirow{2}{*}{$\begin{array}{l}\text { Length of } \\
\text { current } \\
\text { shoot } \\
\quad(\mathrm{cm})\end{array}$} & \multicolumn{2}{|c|}{ Flower } & \multirow{2}{*}{$\begin{array}{l}\text { Number } \\
\text { of petals }\end{array}$} & \multicolumn{3}{|c|}{ Largest leaf } & \multicolumn{2}{|c|}{ Total leaves } \\
\hline & & & $\begin{array}{l}\text { Diameter } \\
(\mathrm{cm})\end{array}$ & $\begin{array}{l}\text { Weight } \\
(\mathrm{g})\end{array}$ & & $\begin{array}{l}\text { Petiole length } \\
(\mathrm{cm})\end{array}$ & $\begin{array}{l}\text { Width } \\
(\mathrm{cm})\end{array}$ & $\begin{array}{l}\text { Length } \\
(\mathrm{cm})\end{array}$ & $\begin{array}{l}\text { Weight } \\
(\mathrm{g})\end{array}$ & $\begin{array}{l}\text { Area } \\
\left(\mathrm{cm}^{2}\right)\end{array}$ \\
\hline 1 & $28.6 \mathrm{a}^{\mathrm{y}}$ & $27.1 \mathrm{ab}$ & 13. $2 \mathrm{ab}$ & $16.8 \mathrm{a}$ & $76.7 \mathrm{ab}$ & $4.0 \mathrm{~b}$ & $9.5 \mathrm{~b}$ & $11.4 \mathrm{~b}$ & $4.1 \mathrm{~b}$ & $154 \mathrm{~b}$ \\
\hline 2 & $35.6 \mathrm{a}$ & 27. $6 \mathrm{ab}$ & 13. $8 \mathrm{ab}$ & $18.4 \mathrm{a}$ & $86.4 \mathrm{a}$ & $6.8 \mathrm{ab}$ & $11.9 \mathrm{ab}$ & 16. $1 \mathrm{ab}$ & 9. $3 a b$ & $362 \mathrm{ab}$ \\
\hline 3 & $39.7 \mathrm{a}$ & $31.6 \mathrm{a}$ & $15.4 \mathrm{a}$ & $16.8 \mathrm{a}$ & $55.2 \mathrm{bc}$ & $10.0 \mathrm{a}$ & $14.2 \mathrm{a}$ & $20.7 \mathrm{a}$ & $12.8 \mathrm{a}$ & $508 \mathrm{a}$ \\
\hline 4 & $35.4 \mathrm{a}$ & $25.7 \mathrm{~b}$ & $13.6 \mathrm{~b}$ & $13.5 \mathrm{a}$ & $45.0 \mathrm{c}$ & $7.9 \mathrm{a}$ & $13.2 \mathrm{a}$ & $18.0 \mathrm{a}$ & 12. $3 \mathrm{a}$ & $416 \mathrm{a}$ \\
\hline
\end{tabular}

Table 8. Effect of precooling and the temperature of cold storage on the dry matter of cut flowers of forced tree paeony (experiment 2).

\begin{tabular}{|c|c|c|c|c|c|c|c|c|}
\hline \multirow[b]{2}{*}{ Section ${ }^{z}$} & \multicolumn{3}{|c|}{ Dry matter } & ? & expe & $=$ & \multicolumn{2}{|l|}{ Partition of dry matter } \\
\hline & $\begin{array}{c}\text { Stem } \\
(\mathrm{g})\end{array}$ & $\begin{array}{l}\text { Leaf } \\
(\mathrm{g})\end{array}$ & $\begin{array}{l}\text { Flower } \\
(\mathrm{g})\end{array}$ & $\begin{array}{c}\text { Total } \\
(\mathrm{g})\end{array}$ & & Stem & $\begin{array}{l}\text { Leaf } \\
\text { (\% of total dry matter) }\end{array}$ & Flower \\
\hline 1 & $1.47 \mathrm{a}^{\mathrm{y}}$ & $0.95 b$ & 3. $31 \mathrm{a}$ & $5.70 \mathrm{~b}$ & 25.1 & $(30.0)^{\mathrm{x}} \mathrm{a}$ & $15.9(23.5) b$ & $59.0(50.1) \mathrm{a}$ \\
\hline 2 & $1.57 \mathrm{a}$ & $2.02 \mathrm{ab}$ & $3.50 \mathrm{a}$ & 7. $09 \mathrm{ab}$ & 22.1 & $(28.0) \mathrm{b}$ & $27.8(31.8) a$ & $50.1(45.0) \mathrm{ab}$ \\
\hline 3 & $1.96 \mathrm{a}$ & $2.96 \mathrm{a}$ & $3.38 \mathrm{a}$ & $8.30 \mathrm{a}$ & 23.9 & $(29.2) a b$ & $34.6(36.0) \mathrm{a}$ & $41.5(40.1) \mathrm{b}$ \\
\hline 4 & $1.84 \mathrm{a}$ & 2. $82 \mathrm{a}$ & $2.84 \mathrm{a}$ & $7.50 \mathrm{a}$ & 24.8 & $(29.8) a b$ & $37.2(37.5) \mathrm{a}$ & $38.1(38.1) b$ \\
\hline
\end{tabular}

see Fig. 2.

${ }^{y}$ Means of flowered plants, separated by Duncan's multiple range test, $5 \%$ level.

${ }^{x}$ Arcsin $\sqrt{\text { percentage. }}$

る. 予備冷蔵を施した区-3は，ほぼすべての形質につい て他 3 処理区より優れた。 区-1 は切花重や葉の諸形質 なぞ他 3 処理区より劣った。 区- 1,2 の花弁数は区-3, 4 のそれより多く, 実験 1 の場合と同様に, 予備冷蔵処理 区は花升の減少が認められた。しかし，逆に葉の諸形質 は予備冷蔵によって良好となった。

促成ボタンの乾物重は第 8 表に示すとおりである，新 鮮重之同様, 区- 1 の葉乾重量や個体乾重量他他 3 処理 区より劣った。また，器官別乾物割合で，区一早葉の割 合は他 3 処理区より低率となったが，花では逆に高率と なった。

\section{考察}

ボタンの促成栽培を行うためには，その花芽の発育過 程を的確に把握することが重要である．春咲きボタンの 花芽分化については, 萩屋の報告 $(2,3)$ が知られており， 青木・吉野(1)によってさらに明らかにされた。それら の報告によれば，雄ずい形成開始時期は 9 月下旬ごろで ある. 從来から, 経験的に行われてきた促成ボタンの冷 蔵開始時期汢 9 月下旬 10 月上旬であり, 雄ずい形成 期前後に 相当する. 冷蔵方法として掘り上げ直後から 0〜 $3^{\circ} \mathrm{C} て ゙ 30 \sim 40$ 日間の低温処理が行われてきたが，開 花率が不安定でしかも良質の切花が得られ難かった(6). また, 前報(1)や本実験 1 の結果からも明らかなように,
雄ずい形成期前後の 2 年生株を供試し, 予備冷蔵を施さ ず直ちに $0^{\circ} \mathrm{C}$ での本冷蔵後促成した場合には, 開花率 が低かったり, 実験 2 のように, 冷蔵期間が 1 週間短か ったことが原因とも考兄られるが，切花品質の劣悪化が 認められた．したがって，雄ずい分化期前後の株につい ては, $0^{\circ} \mathrm{C}$ での単独冷蔵は好なしくないと考兄る。

予借冷蔵の影響については, 期間が長くなるほど本冷 蔵開始時の花弁数の增加が認められることから, 花芽形 成のステージが幾分進んだことが確認された。 また，促 成結果は萠芽期や開花期が早くなり, 予借冷蔵の効果が 著しく現れた。この点について, 細木ら(5)も同様な結 果を得ている.しかしながら, 開花率は本冷蔵温度や苗 龄によって著しく異なるものである.すなわち， 2 年生 株では, $4^{\circ} \mathrm{C}$ の場合, 3 週間の予備冷蔵によって開花率

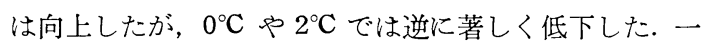
方, $3 \sim 4$ 年生株では, 開花率に対して本冷蔵の温度が 影響を与えておらず，促成に使用する株の苗龄によっ て，本冷蔵温度を変化させる必要があるものと考之る。

予備冷蔵された株は, 本冷蔵開始時の花弁数が無処理 区より多かったのにもかかわらず，本冷蔵温度の高低に 関係なく促成切花の花升数が減じた。この理由として， 前述したように予備冷蔵することによって本冷蔵開始時 の花芽形成のステージが進み，その後の花芽形成は花弁 
の分化より雄ずい形成が優先して行われた結果によるも のと考えられる。なお，前報(1)や本実験で観察された ように，促成切花時の花升数は雄ずい形成時の花弁数に 比べ著しく多い。このことは, 冷蔵中の何らかの刺激に より，雄ずいから花弁への転換が促された結果であろ 万.

花升数は本冷蔵温度によっても多少異なったが， $0^{\circ} \mathrm{C}$ 冷蔵は $2^{\circ} \mathrm{C} や 4^{\circ} \mathrm{C}$ 冷蔵より多い傾向を示した.このこ とについて, $2^{\circ} \mathrm{C} や 4^{\circ} \mathrm{C}$ 冷蔵では花芽形成が徐々に進行 するのではないかと考兄れるのに対し， $0^{\circ} \mathrm{C}$ 冷蔵では 前報(1)でも述べたようにほとんど進行せず，花芽形成 が阻止された状態であった。したがって，本冷蔵温度に よって生ずる促成切花の花弁数の差の原因については, 今後の追究が必要である.

促成ボタンの葉面積は, 本冷蔵のみでは冷蔵温度が高 くなるほど増加したのに対し， 3 週間の予備冷蔵を行兄 ば $0^{\circ} \mathrm{C}$ の場合にのみその増加は顕著であり, $4^{\circ} \mathrm{C} て ゙ は$ 逆 に減少傾向が認められた。李ら $(7,8)$ はイチゴにおいて, 休眼打破が不十分な場合に葉柄や葉身長が短くなる傾向 を認めている，一方，林(4)はアイリスにおいて，冷蔵が 効き過ぎると, 茎長が短く, 葉の伸長が抑制されるが, 逆に冷蔵が弱いと草丈がよく伸長するとしている，促成 ボタンでは前報(1)や本実験結果から 総合的に判断する と, 休眠打破が不十分な場合には李らと同様な結果が得 られる・また, 高い冷蔵温度で休眠打破が十分に行われた 場合には，低い場合より葉面積は增大するものと思われ る。ただし，予備冷蔵を施し休眠打破を早めた場合に は, 本冷蔵温度が低い場合に予備冷蔵の効果が加わり, 葉面積の増大が図られるものと思われる.

本実験での予侕冷蔵温度は $15^{\circ} \mathrm{C}$ であったが，その時 期における外気温の平均温度は $20^{\circ} \mathrm{C}$ 前後であり, 約 5 ${ }^{\circ} \mathrm{C}$ の差があった。 この $5^{\circ} \mathrm{C}$ の差や期間が適当であるか 追究を必要とされる。すなわち，実験 2 のようにわずか 1 週間だけ $8^{\circ} \mathrm{C}$ 冷蔵を施すことによって, $0^{\circ} \mathrm{C}$ 冷蔵を継 続したものより萠芽期や開花期が早く, 切花品質も優れ る. 一方, $15^{\circ} \mathrm{C}$ で予備冷蔵されたものについては, $8^{\circ} \mathrm{C}$ 冷蔵の插入によって開花期はやや遅れ, 有意差はないも のの切花品質がやや劣る傾向が認められるからである.

以上の上うに, ボタンの促成では予備冷蔵によって萠 芽期や開花期が早められ, 2 年生株では $4^{\circ} \mathrm{C}$ 冷蔵との組 み合わせによって開花率は高くなり，80\%の実用限界 を越えた。一方，花弁数や葉面積は減少したが，“花競” は通常 100 枚前後の花弁数を有する多重弁種であり, 花弁数が減少しても花径に変化はなく，30４0 枚の花 弁数でも切花には十分であると推察されだ。また，全葉
面積では $400 \mathrm{~cm}^{2}$ 以上であり, 切花の草姿として劣るも のではなかった．したがって，2 年生株での促成は， $4^{\circ} \mathrm{C}$ 冷蔵と予備冷蔵の組み合わせが有効と考える。 また, $3 \sim 4$ 年生株でも 2 年生株之同様, 予借冷蔵によって萠 芽期や開花期が早まったが， 2 年生株の場合と異なり， 冷蔵温度は開花率に対しあまり影響を及ぼさないようで ある、これは, 促成株の苗龄の違いから起因する栄養条 件の差によって生じてくるものであるう.したがって, $3 \sim 4$ 年生株での促成は, 予備冷蔵を施せば $0^{\circ} \mathrm{C} 6$ 週間 冷蔵でも有効であることが示唆された。

\section{摘 要}

予備冷蔵の有無と冷蔵温度の違いが, 促成ボタンの生 育及び切花品質に与える影響について調查した。

\section{実験 1 .}

1. $15^{\circ} \mathrm{C}$ の予備冷蔵期間が 長くなるほど 本冷蔵開始 時の花弁数が増加し, 予備冷蔵によって花芽形成のステ ージが進んだ.

2. 予供冷蔵を施すことによって萠芽期が早くなり， 開花期も早かった。予備冷蔵をしない $0^{\circ} \mathrm{C}$ 冷蔵区では, 他処理区上り萠芽期が $1 \sim 2$ 週間, 開花期が 2 週間以上 遅延した。

3. 予供冷蔵 3 週間と $4{ }^{\circ} \mathrm{C}$ 本冷蔵を組み合わせた処 理区の開花率は $81.2 \%$ で最も高く, 予借冷蔵と $0^{\circ} \mathrm{C}$ の それは $12.5 \%$ で最も低率であった。

4. 開花時に打ける切花品質は, $4^{\circ} \mathrm{C}$ 冷蔵区と予備冷 蔵を施した $0^{\circ} \mathrm{C}$ 冷蔵区が優れ, 予備冷蔵を施さない $0^{\circ} \mathrm{C}$ 冷蔵区は劣った。

5. 2 週間以上予倫冷蔵すると, 本冷蔵のみの区上り 切花の花弁数が減少した.

\section{実験 2 .}

1. 実験 1 と同様, 予備冷蔵によって萠芽及び開花期 が著しく早くなり，しかも切花品質は良好であった，し かし花弁数は減少した。

2. 開花率は全処理区とも 80 ～100\% と高率であっ た.

以上の結果から, 2 年生株での促成は $4^{\circ} \mathrm{C}$ 冷蔵と予備 冷蔵 3 週間の組み合わせが有効と考えられる。また, $3 \sim 4$ 年生株では, 予備冷蔵を施せば $0^{\circ} \mathrm{C} 6$ 週間冷蔵で も有効であることが示㖫された。

\section{引用文献}

1. 青木宣明・吉野蕃人. 1984。冷蔵期間が促成ボ夕 ンの生育及び切花品質に及ぼす影響. 園学雑. $52: 450-457$.

2. 萩屋 薰. 1960. ボタン及びシャクヤクの花芽の 分化. 生丹. $10: 8-13$. 
3. 萩屋 薰. 1961. ボタン品種の花芽の分化. 特に 寒ボタンの二季咲性について。牡丹. $11: 11$ 一 16.

4. 林 角郎. 1977. アイリスの開花調節技術. 農耕 之園芸. 37(4)：140-145.

5. 細木高志・浜田守彦・稲葉久仁雄. 1984. 薬剤お よび予備冷蔵処理によるボタンの 12 月促成開 花. 園学要旨. 昭 59 春 : $374-375$.

6. 小杉 清. 1976. 花木の開花生理と栽培. p.
304-309. 博友社. 東京.

7. 李 炳馹・高橋和彦・杉山直儀. 1968. イチゴの 休眠に関する研究. 第 1 報. 保温開始時期がイチ ゴの発育におよぼす影響の品種間差異. 園学雑. $37: 129-134$.

8. 李 炳馹・高橋和彦・杉山直儀. 1970. イチゴの 休眠に関する研究. 第 2 報. 保温開始期と日長が ダナーの生長, 開花, 結実に及ぼす影響. 園学 雑. $39: 232-238$. 